\title{
PENGARUH RELIGIUSITAS DAN PENGETAHUAN AKUNTANSI SYARI'AH TERHADAP MINAT MAHASISWA AKUNTANSI BERKARIR DI LEMBAGAKEUANGAN SYARI'AH: STUDI PADA MAHASISWA AKUNTANSI KONSENTRASI SYARI'AH
}

\author{
Dian Ariska \\ Prodi Akuntansi Universitas Muhammadiyah Palopo \\ dianariska@gmail.com
}

\begin{abstract}
ABSTRAK
Penelitian ini bertujuan untuk mengetahui pengaruh religiusitas dan pengetahuan akuntansi syariah terhadap minat mahasiswa akuntansi berkarir di lembaga keuangan syariah pada universitas muhammadiyah palopo fakultas ekonomi dan bisnis. Metode pengumpulan data dalam penelitian ini adalah metode angket yaitu menyebarkan daftar pernyataan (kuesioner) yang akan diisi atau dijawab oleh responden pada mahasiswa yang mengambil kosentrasi akuntansi syariah. Untuk mengelola dan menganalisis data yang diperoleh serta membuat kesimpulan penelitian digunakan analisis kuantitatif dengan teknik analisis regresi linear berganda yang bertujuan untuk memperoleh gambaran yang menyeluruh mengenai hubungan antar variabel dengan bantuan program SPSS (Statistical Package For Social Sciences) Versi 2.2. Hasil pengujian menunjukkan bahwa religiusitas tidak berpengaruh secara signifikan terhadap minat mahasiswa akuntansi berkarir di lembaga keuangan syariah, sedangkan pengetahuan akuntansi syariah berpengaruh secara signifikan terhadap minat mahasiswa akuntansi berkarir di lembaga keuangan syariah. Kemampuan prediksi dari kedua variabel tersebut terhadap minat mahasiswa akuntansi berkarir di lembaga keuangan syariah sebesar 95\% sedangkan sisanya dipengaruhi oleh faktor lain dari luar.
\end{abstract}

Kata Kunci : Religiusitas, Pengetahuan Akuntansi Syariah, dan Minat Berkarir di Lembaga Keuangan Syariah

\section{ABSTRACT}

This study aims to determine the effect of religiosity and knowledge of sharia accounting on the interests of career accounting students in Islamic financial institutions at the Muhammadiyah University of Palopo, Faculty of Economics and Business. The data collection method in this study is a questionnaire method that is to spread a list of statements (questionnaires) that will be filled or answered by respondents to students who take sharia accounting concentration. To manage and analyze the data obtained and make research conclusions used quantitative analysis with multiple linear regression analysis techniques that aim to achieve a comprehensive picture of the relationship between variables with the help of SPSS (Statistical Package for Social Sciences) Version 2.2. The test results show that religiosity does not significantly influence career accounting students' interests in Islamic financial institutions. In contrast, the knowledge of Islamic accounting substantially affects the importance of career accounting students in Islamic financial institutions. The predictive ability of these two variables on the interests of career accounting students at Islamic financial institutions is 95\%, while other factors from the outside influence the rest.

Keywords: Religiosity, Knowledge of Sharia Accounting, and Career Interests in Islamic Financial Institution

\section{PENDAHULUAN}

Pesatnya perkembangan dunia bisnis memberikan lapangan pekerjaan yang beragam untuk angkatan kerja, terutama kemajuan dunia bisnis syariah di Indonesia tentu harus diiringi dengan infrastruktur yang memadai, termasuk tenaga ahli yang membidangi bisnis syariah itu sendiri.

Perkembangan bisnis syariah di Indonesia cukup pesat dimulai dengan didirikannya Bank Muamalat pada tahun 1992 sebagai pelopor berdirinya bank syariah pertama di Indonesia 
yang kemudian diikuti dengan lembaga-lembaga syariah lainnya seperti lembaga keuangan mikro syariah, baitul mal, berbagai asuransi syariah, lembaga filantropi lainnya, bahkan hotel dan usaha yang bercirikan syariah mulai mewabah saat ini. Hal ini tidak terlepas dari prospek yang baik di sektor keuangan syariah di Indonesia, dan dengan disahkannya Undang-Undang No. 21 Tahun 2008 tentang Perbankan Syariah (Nurhayati \& Wasilah, 2012).

Perkembangan dalam dunia bisnis syariah tersebut harus selalu direspon oleh sistem pendidikan yang baik terutama dibidang akuntansi syariah. Agar dapat menghasilkan sarjana akuntansi syariah yang bekualitas dan siap pakai di dunia kerja. Untuk dapat mencapai tujuan tersebut maka desain pendidikan akuntansi Syariah harus relevan terhadap dunia kerja bagi sarjana akuntansi syariah (Dian \& Ardiani, 2011). Sejalan dengan itu, saat ini telah banyak perguruan tinggi membuka program studi syariah baik di perguruan tinggi negeri maupun perguruan tinggi swasta.

Minat dan rencana karir mahasiswa akuntansi akan sangat berguna bagi akademisi dalam mendesain kurikulum dan proses belajar mengajar yang lebih efektif sesuai dengan pilihan profesi mahasiswa. Oleh karena itu, diperlukan suatu stimulasi untuk membuat mahasiswa mulai memikirkan secara serius tentang karir yang diinginkan sejak masih di bangku kuliah agar mahasiswa dapat memanfaatkan waktu dan fasilitas kampus secara optimal (Sari, 2013).

Menurut Reni dan Puji (2013) untuk menunjang tercapainya tujuan mahasiswa dalam pemilihan karir pihak akademisi menyediakan fasilitas, seperti dengan menyediakan buku yang sesuai dengan perkembangan dunia bisnis syariah, mengadakan pelatihan, mengadakan tugas magang dan sebagainya. Sehingga setelah selesai pendidikannya, diharapkan mahasiswa mampu menyesuaikan diri dengan tuntutan dalam pekerjaan.

Mahasiswa akuntansi syariah dipersiapkan dan dibekali ilmu yang mendalam tentang akuntansi syariah. Ilmu-ilmu yang dipelajari di bangku kuliah akan menjadi bekal ketika ingin bekerja di lembaga keuangan syariah setelah lulus nanti. Peluang untuk berkarir di lembaga keuangan syariah maupun kesempatan untuk menjalankan bisnis pun terbuka lebar bagi lulusan akuntansi syariah.

Namun tidak semua lulusan akuntansi syariah berminat untuk bekerja di lembaga keuangan syariah. Banyak dari lulusan akuntansi syariah yang bekerja di lembaga konvensional, menjadi akuntan publik, akuntan pendidik, akuntan manajamen, akuntan pemerintah dan 
bahkan ada yang berwirausaha.

Hal ini disebabkan oleh banyak faktor yang mempengaruhi minat untuk menjadi karyawan di lembaga keuangan syariah seperti faktor religiusitasitas, pengetahuan akuntansi syariah, pelatihan profesional dan pertimbangan pasar kerja.

Oleh karena itu Perguruan Tinggi yang berbasis islam sebagai agen perubahan (agent of change), yang merupakan wadah dimana harapan lahirnya SDM yang memiliki kompetensi dan keahlian yang dibutuhkan oleh dunia kerja. Profesionalisme dan mental spiritual yang baik menjadi daya dukung utama dalam menjawab tantangan dunia kerja saat ini dan di masa mendatang.

Faktor-faktor yang mempengaruhi pemilihan karir mahasiswa dan jenis karir yang akan mereka jalani merupakan hal menarik untuk diteliti karena dengan diketahuinya pilihan karir yang diminati mahasiswa, maka dapat diketahui mengapa seseorang memilih karir tersebut. Minat dan rencana karir yang jelas akan sangat berguna dalam program penyusunan materikuliah dapat disampaikan secara efektif bagi mahasiswa yang memerlukannya (Nanang, 2014).

Hasil penelitian dari Nanang Agus Suyono (2014) tentang analisis factor-faktor yang mempengaruhi pemilihan karir sebagai akuntan publik, menunjukan bahwa secara parsial faktor penghargaan finansial, pelatihan profesional, nilai-nilai sosial, pertimbangan pasar kerja dan personalitas memiliki pengaruh yang signifikan terhadap pemilihan karir sebagai akuntan publik oleh mahasiswa akuntansi di Universitas Sains Al Qur’an.

Sedangkan faktor pengakuan profesional dan lingkungan kerja tidak memiliki pengaruh yang signifikan terhadap pemilihan karir sebagai akuntan publik oleh mahasiswa akuntansi di Universitas Sains Al Qur'an.

Hasil penelitian Fajar dan Zulaikha (2013) tentang analisis faktor-faktor yang mempengaruhi pemilihan karir mahasiswa akuntansimenjelaskan bahwa faktor penghargaan finansial, pelatihan profesional, pengakuan profesional, pertimbangan pasar kerja, dan peran gender berpengaruh signifikan sebagai faktor-faktor pemilihan karir mahasiswa sebagai akuntan publik atau akuntan non publik.

Hasil penelitian Sari (2013) menunjukan bahwa penghargaan finansial, pelatihan professional, pengakuan profesional, nilai-nilai sosial, lingkungan kerja, dan pertimbangan pasar kerja berpengaruh terhadap minat menjadi akuntan publik. 
Hasil penelitian dari Dian dan Ardiani (2011) menunjukan bahwa faktor finansial, lingkungan kerja, pertimbangan pasar kerja dan personalitas tidak berpengaruh dalam pemilihan karir mereka sebagai akuntan publik atau non akuntan, sedangkan pelatihan profesional dan nilainilai sosial mempunyai pengaruh yang signifikan terhadap pemilihan karir sebagai akuntan publik.

Penelitian dari Ardiani dkk (2013) tentang persepsi mahasiswa akuntansi mengenai faktorfaktor yang mempengaruhi pemilihan karir, menunjukan bahwa ada perbedaan persepsi mahasiswa dalam pemilihan karir gaji, pelatihan profesional, pengakuan profesional, linkungan kerja dan pertimbangan pasar tenaga kerja merupakan hal-hal yang bisa menyebabkan perbedaan persepsi dalam pemilihan karir. Penelitian dari Widyasari (2010) menunjukan hasil bahwa ada perbedaan persepsi mengenai pemilihan karir yang ditinjau dari faktor gaji, pelatihan profesional, pengakuan profesional, nilai-nilai sosial, lingkungan kerja, pertimbangan pasar kerja. Sedangkan ditinjau dari personalitas tidak ada perbedaan.

Berdasarkan deskripsi diatas, penulis tertarik untuk melakukan penelitian yang berjudul "Pengaruh Religiusitas Dan Pengetahuan Akuntansi Syari'ah Terhadap Minat Mahasiswa Akuntansi Berkarir Di Lembaga Keuangan Syari'ah (Studi Pada Mahasiswa Akuntansi Konsentrasi Syari'ah)".

\section{METODE PENELITIAN}

\section{Jenis dan Sumber Data}

Jenis data yang digunakan dalam penelitian ini adalah jenis data Kuantitatif. Data tersebut berupa nilai atau skor atas jawaban yang diberikan oleh responden terhadap pertanyaanpertanyaan yang terdapat dalam kuesioner.

Sumber data yang digunakan dalam penelitian ini yaitu data primer. Data primer merupakan data penelitian yang diperoleh secara langsung dari responden melalui penyebaran kuisioner pada Mahasiswa Akuntansi Syariah Universitas Muhammadiyah Palopo. Data ini merupakan respon tertulis dari responden yang dijadikan sampel penelitian dan diolah menggunakan aplikasi SPSS (Statistical Package For Social Sciences).

\section{Tehnik Pengumpulan Data}

Data dikumpulkan melalui metode angket, yaitu menyebarkan daftar pertanyaan (kuesioner) yang akan diisi atau dijawab oleh responden pada mahasiswa yang mengambil kosentrasi 
akuntansi syariah di Universitas Muhammadiyah Palopo Fakultas Ekonomi dan Bisnis. Kuesioner merupakan teknik pengumpulan data yang dilakukan dengan cara memberi seperangkat pertanyaan atau pernyataan tertulis kepada responden untuk di jawabnya (Sugiyono, 2010:199)

Skala yang digunakan dalam penelitian ini adalah skala Likert. Skala Likert adalah skala yang berisi lima tingkat preferensi jawaban dengan pelihan sebagai berikut :

$$
\begin{aligned}
& 1 \text { = Sangat tidak setuju } 2=\text { Tidak setuju } \\
& 3 \text { = Kurang setuju } 4=\text { Setuju } \\
& 5 \text { = Sangat setuju }
\end{aligned}
$$

\section{Waktu dan Tempat Penelitian}

Penelitian ini dilakukan di Universitas Muhammadiyah Palopo, Fakultas Ekonomi dan Bisnis, yang beralamat di Jalan Jend. Sudirman. Waktu penelitian dimulai tanggal 11 April sampai 11 Juni 2019.

\section{HASIL DAN PEMBAHASAN}

Hasil penyebaran kuesioner secara langsung kepada mahasiswa akuntansi syariah Universitas Muhammadiyah Palopo. Jumlah kuesioner yang disebar adalah 76, dari 76 kuesioner yang disebar tersebut yang dapat diolah sejumlah 60 kuesioner yang kemudian diuji dan dianalisis lebih lanjut. Tingkat pengembalian kuesioner yang dapat diolah lebih lanjut akan disajikan dalam Tabel 1. Tabel 1 mengklasifikasikan bahwa kuesioner yang disebarkan sejumlah 76 buah. Kuesioner yang kembali adalah 60 buah atau dengan kata lain tingkat pengembalian kuesioner adalah $78,95 \%$.

Tabel 1.

\begin{tabular}{|l|l|c|}
\hline No & Keterangan & Jumlah \\
\hline 1 & Kuesioner yang disebarkan ke mahasiswa akuntansi syariah & 76 \\
\hline 2 & Kuesioner yang direspon/dikembalikan & 60 \\
\hline 3 & Kuesioner yang tidak direspon & 16 \\
\hline
\end{tabular}




\begin{tabular}{|l|l|l|}
\hline 4 & Tingkat Pengembalian & $60 / 76 \times 100 \%=78,95 \%$ \\
\hline
\end{tabular}

Tabel 2 Uji Validitas Religiusitas X1

\begin{tabular}{|c|c|c|c|}
\hline Indikator & R hitung & $\mathrm{R}$ tabel & Keterangan \\
\hline X1.I & 0,520 & 0,2542 & Valid \\
\hline X1.2 & 0,519 & 0,2542 & Valid \\
\hline X1.3 & 0,770 & 0,2542 & Valid \\
\hline X1.4 & 0,564 & 0,2542 & Valid \\
\hline X1.5 & 0,448 & 0,2542 & Valid \\
\hline X1.6 & 0,770 & 0,2542 & Valid \\
\hline
\end{tabular}

Sumber data diolah SPSS 2019

Tabel 3 Uji Validitas Pengetahuan Akuntansi Syariah X2

\begin{tabular}{|l|l|l|l|}
\hline Indikator & R hitung & R tabel & Keterangan \\
\hline X2.1 & 0,593 & 0,2542 & Valid \\
\hline X2.2 & 0,514 & 0,2542 & Valid \\
\hline X2.3 & 0,803 & 0,2542 & Valid \\
\hline X2.4 & 0,808 & 0,2542 & Valid \\
\hline X2.5 & 0,803 & 0,2542 & Valid \\
\hline
\end{tabular}

Tabel 4 Uji Validitas Minat Berkarir di Lembaga Keuangan Syariah Y

\begin{tabular}{|c|c|c|c|}
\hline Indikator & R hitung & $\mathrm{R}$ tabel & Keterangan \\
\hline Y1.1 & 0,655 & 0,2542 & Valid \\
\hline
\end{tabular}

Dian Ariska 20|28 


\begin{tabular}{|c|c|c|c|}
\hline Y1.2 & 0,647 & 0,2542 & Valid \\
\hline Y1.3 & 0,641 & 0,2542 & Valid \\
\hline Y1.4 & 0,853 & 0,2542 & Valid \\
\hline
\end{tabular}

Sumber data diolah SPSS 2019

Berdasarkan tabel uji validitas religiusitas (XI), pengetahuan akuntansi syariah (X2), dan minat berkarir dilembaga keuangan syariah (Y), di atas dapat disimpulkan bahwa semua item pernyataan untuk masing-masing variabel dinyatakan valid. Hal ini dapat dilihat dari hasil $r$ hitung, dimana $r$ hitung $>r$ tabel maka pernyataan dikatakan valid.

Tabel 5 Uji Reabilitas

\begin{tabular}{|l|c|c|c|}
\hline \multicolumn{1}{|c|}{ Variabel } & Cronbach's Alpha & Nilai Alpha & Keterangan \\
\hline Religiusitas & 0,648 & 0,60 & Reliabel \\
\hline Pengetahuan Akuntansi Syariah & 0,741 & 0,60 & Reliabel \\
\hline Minat Berkarir & 0.638 & 0,60 & Reliabel \\
\hline
\end{tabular}

Sumber data diolah SPSS 2019

Dari hasil uji reliabilitas pada tabel di atas, semua variabel yang dijadikan instrumen dalam penelitian ini adalah reliabel atau handal karena menunjukan tingkat reliabilitas yang tinggi. Hal ini dibuktikan dengan nilai koefisien Alpha lebih dari 0,60 sehingga dapat digunakan sebagai alat ukur yang handal atau dapat dipercaya.

Uji asumsi klasik pertama yang dilakukan yaitu uji normalitas. Uji normalitas menggunakan uji kolmogorov smirnov. Nilai p value sebesar 0,200>0,05, sehingga distribusi data pada model regresi ini bersifat normal. Uji Multikolinieritas, menurut Ghozali (2013) untuk menguji ada tidaknya gejala multikolinieritas digunakan VIF (Variance Inflacition Factor). Jika nilai VIF dibawah 10 maka model regresi yang diajukan tidak terdapat gejala multikolinieritas, begitu sebaliknya jika VIF lebih besar 10 maka terjadi gejala multikolinieritas. Berdasarkan pengujian diproleh nilai VIF untuk seluruh variabel bebas 
memiliki nilai VIF dibawah 10, sehingga model regresi yang diajukan dalam penelitian ini tidak mengandung gejala multikolinieritas. Selanjutnya adalah pengujian heteroskedastisitas. Gejala heterokedastisitas terjadi bila distrurbance term untuk setiap observasi tidak lagi konstan, tetapi bervariasi. Perhitungan heterokedastisistas dapat dilakukan Uji F Pengujian ini dilakukan untuk mengetahui pengaruh seluruh variabel independen secara bersamasama atau simultan terhadap variabel dependen dengan menggunakan uji $\mathrm{F}$ dengan tarif signifikansi 5\% . Jika dalam banyak model, salah satunya adalah model. Nilai VIF untuk seluruh variabel bebas memiliki nilai sig t atau $p$ value diatas 0,05 sehingga model regresi yang diajukan dalam penelitian ini tidak mengandung gejala heterokedasitas. nilai signifikansi uji $\mathrm{F}$ lebih kecil dari 5\% maka terdapat pengaruh antara semua variabel independen terhadap variabel dependen. Hasil pengujian uji F dapat dilihat pada tabel berikut ini:

Tabel 6 Hasil Pengujian Simultan (Uji F): ANOVA ${ }^{a}$

\begin{tabular}{|ll|l|l|l|l|l|}
\hline Model & Sum of Squares & Df & Mean Square & F & Sig. \\
\hline $1 \quad$ Regression & 116,801 & 2 & 58,401 & 561,180 &, $000^{\mathrm{b}}$ \\
\cline { 3 - 5 } & Residual & 5,932 & 57 &, 104 & & \\
Total & 122,733 & 59 & & & \\
\hline
\end{tabular}

Dependent Variable: MINAT

Predictors: (Constant), PAS, RELIGIUS

Sumber data diolah SPSS 2019

Berdasarkan uji $\mathrm{F}$ diperoleh hasil bahwa nilai $\mathrm{F}$ hitung sebesar 561,180 dengan tingkat signifikan sebesar $0,000 \%$. F hitung $(561,180)>F_{\text {tabel }}(2,77)$ maka secara simultan religiusitas (X1), pengetahuan akuntansi syariah (X2), mempunyai pengaruh terhadap minat berkarir di lembaga keuangan syariah (Y).

Uji t digunakan untuk menguji signifikansi pengaruh masing-masing variabel independen yang diuji pada tingkat signifikansi 0,05 (Ghozali, 2013). Teknik yang digunakan yaitu dengan membandingkan nilai $\mathrm{t}$ hitung dengan $\mathrm{t}$ tabel, $\mathrm{t}$ tabel dapat dicari dengan signifikansi 0,05 dengan rumus $n-k, n=60$ dan $\mathrm{k}=$ jumlah seluruh variabel yaitu 3. Maka didapat $\mathrm{t}$ tabel sebesar: 
Tabel 7 Hasil Pengujian Parsial (Uji t): Coefficients ${ }^{\mathbf{a}}$

\begin{tabular}{|c|c|c|c|c|c|c|}
\hline \multirow{2}{*}{\multicolumn{2}{|c|}{ Model }} & \multicolumn{2}{|c|}{ Unstandardized Coefficients } & \multirow{2}{*}{$\begin{array}{l}\text { Standardized } \\
\text { Coefficients } \\
\text { Beta }\end{array}$} & \multirow[b]{2}{*}{$\mathrm{T}$} & \multirow[b]{2}{*}{ Sig. } \\
\hline & & $\mathrm{B}$ & Std. Error & & & \\
\hline \multirow[t]{3}{*}{1} & (Constant) & 1,936 & ,796 & & 2,431 &, 018 \\
\hline & RELIGIUS &,- 040 &, 022 &,- 054 & $-1,836$ &, 072 \\
\hline & PAS & ,759 &, 023 & ,970 & 33,206 &, 000 \\
\hline
\end{tabular}

Dependent Variable: MINAT

Sumber data diolah SPSS 2019

Untuk mencari $\mathrm{t}$ tabel Berdasarkan tabel diatas, dapat diketahui bahwa religiusitas mempunyai $\mathrm{t}$ hitung $=-1,836<\mathrm{t}$ tabel $=1,67203$ dengan tingkat signifikansi sebesar $0,72>$ 0,05, maka H0 diterima dan Ha ditolak. Religiusitas tidak berpengaruh secara signifikan terhadap minat mahasiswa akuntansi berkarir di lembaga keuangan syariah.

Pengaruh Religiusitas Terhadap Minat Mahasiswa Akuntansi Berkarir di Lembaga Keuangan Syariah.

\section{Hasil penelitian menunjukkan religiusitas tidak berpengaruh signifikan terhadap minat mahasiswa berkarir di lembaga keuangan syariah.}

Sejalan dengan teori pilihan rasional bahwa seluruh perilaku sosial disebabkan oleh perilaku individu yang masing-masing membuat keputusannya sendiri. Teori pilihan rasional (rasional choice) dari James S. Coleman merupakan paradigma tindakan adalah satu-satunya teori yang memiliki peluang menghasilkan integrasi berbagai paradigma sosiologi. Pilihan rasional ini, dijadikan sebagai model penjelasan dari tindakan-tindakan individu yang dimaksudkan untuk memberikan analisa formal dari pengambilan keputusan rasional berdasarkan alasan dan tujuan yang dicapai oleh aktor. Tindakan seseorang secara sengaja mengarah kepada suatu tujuan, dengan tujuan dan juga tindakan yang dilakukan ditentukan oleh nilai atau preferensi. Sesuatu yang dapat dikatan memiliki nilai apabila sesuatu itu memiliki manfaat dan keuntungan untuk kepuasan. George dan Douglas dalam Imroatullayyin (2013).

Pengetahuan akuntansi syariah mempunyai t hitung $=33,206>\mathrm{t}$ tabel $=1,67203$ dengan tingkat signifikansi sebesar 0,000 > 0,05, maka H0 ditolak dan Ha diterima, pengetahuan akuntansi syariah berpengaruh secara signifikan terhadap minat mahasiswa akuntansi berkarir di lembaga keuangan syariah. 
Sejalan dengan penelitian Sri (2017), tentang pengaruh religiusitas, pengetahuan akuntansi syariah, Pelatihan profesional dan pertimbangan pasar kerja terhadap minat mahasiswa akuntansi berkarir di lembaga keuangan syariah. Hasil penelitiannya menunjukan bahwa religiusitas tidak berpengaruh terhadap minat mahasiswa akuntansi berkarir di lembaga keuangan syariah. Sejalan dengan penelitian Makhsun Ali, W (2018), tentang analisis faktorfaktor yang mempengaruhi minat mahasiswa fakultas ekonomi dan bisnis islam.

\section{Pengaruh Pengetahuan Akuntansi Syariah Terhadap Minat Mahasiswa Akuntansi Berkarir Di Lembaga Keuangan Syariah}

Hasil penelitian menunjukkan pengetahuan akuntansi syariah berpengaruh signifikan terhadap minat mahasiswa akuntansi syariah berkarir di lembaga keuangan syariah. semakin tinggi pengetahuan akuntansi syariah yang dimiliki setiap mahasiswa, maka semakin tinggi pula minat berkarir di lembaga keuangan syariah.

Hasil penelitian ini sejalan dengan teori yang dinyatakan oleh Teori Bloom menunjukan bahwa tingkat pengetahuan terdiri dari (Tiyaz \& Rizky, 2017): tingkat pemahaman (comprehension level) yaitu kemampuan untuk menjelaskan pengetahuan yang dipelajari. Tingkat aplikasi (application level), yaitu kemampuan untuk menerapkan pengetahuan yang telah dipelajari dalam suatu tindakan nyata. Tingkat ananalisis (analysis level) yaitu kemampuan untuk menyelidiki pengetahuan yang mereka pelajari. Tingkat sintesis (synthesis level), yaitu kemampuan untuk menghubungkan semua pengetahuan dan mengintegrasikan menjadi sesuatu hal yang baru. Tingkat terakhir adalah tingkat evaluasi IAIN salatiga untuk berkarir di bank syariah. Hasil penelitian menunjukan bahwa religiusitas tidak berpengaruh signifikan terhadap minat berkarir di bank syariah.

(evaluation level) yaitu kemampuan untuk menilai manfaat dari suatu pengetahuan. Dalam teori pengetahuan menjelaskan bahwa semakin tinggi pengetahuan seseorang maka semakin tinggi pula keinginan untuk menerapkan pengetahuan yang telah dipelajari dalam suatu tindakan nyata. Hal ini menunjukan bahwa pengetahuan merupakan salah satu hal terpenting dalam menentukan pimilihan karir seseorang atas apa yang telah diketahui. Sejalan dengan penelitian ini bahwa pengetahuan akuntansi syariah berpengaruh dan signifikan terhadap minat mahasiswa akuntansi berkarir di lembaga keuangan syariah.

Sejalan dengan penelitian fani (2015), tentang faktor-faktor yang mempengaruhi minat mahasiswa akuntansi universitas Bengkulu berkarir di lembaga keuangan syariah. Hasil 
penelitiannya menunjukan bahwa pengetahuan akuntansi syariah berpengaruh terhadap minat mahasiwa akuntansi berkarir di lembaga keuangan syariah.

Sejalan dengan penelitian Linda (2011), tentang Pengaruh Pengetahuan Akuntansi dan Motivasi Terhadap Minat Mahasiswa Akuntansi Perguruan Tinggi Negeri dan Swasta di Provinsi NAD Untuk Mengikuti Pendidikan Profesi Akuntansi (PPAK). Hasil penelitiannya menunjukan bahwa pengetahuan akuntansi berpengaruh terhadap pemilihan karir

\section{SIMPULAN DAN SARAN}

\section{SIMPULAN}

Penelitian ini bertujuan untuk mengetahui pengaruh religiusitas dan pengetahuan akuntansi syariah terhadap minat mahasiswa akuntansi berkarir di lembaga keuagan syariah. Berdasarkan penelitian yang telah dilakukan dapat disimpulkan beberapa hal berikut:

Hasil pengujian statistik secara persial yang telah dilakukan antara variabel Religiusitas (X1) terhadap Minat Mahasiswa Akuntansi Berkarir di Lembaga Keuangan Syariah diperoleh hasil bahwah variabel religiusitas tidak berpengaruh terhadap Minat Mahasiswa Akuntansi Berkarir di Lembaga Keuangan Syariah, begitupun secara simultan variabel religiusitas tidak berpengaruh signifikan terhadap Minat Mahasiswa Akuntansi Berkarir di Lembaga Keuangan Syariah.

Hasil pengujian statistik secara persial yang telah dilakukan antara variabel Pengetahuan Akuntansi Syariah (X2) terhadap Minat Mahasiswa Akuntansi Berkarir di Lembaga Keuangan Syariah diperoleh hasil bahwah variabel Pengetahuan Akuntansi Syariah berpengaruh terhadap Minat Mahasiswa Akuntansi Berkarir di Lembaga Keuangan Syariah, begitupun secara simultan variabel Pengetahuan Akuntansi Syariah berpengaruh signifikan terhadap Minat Mahasiswa Akuntansi Berkarir di Lembaga Keuangan Syariah.

Hasil penelitian Secara simultan religiusitas dan pengetahuan akuntansi syariah berpengaruh terhadap minat mahasiswa akuntansi berkarir di lembaga keuangan syariah.

\section{SARAN}

Untuk mendapatkan hasil yang maksimal diperlukan sampel yang lebih banyak. Peneliti selanjutnya diharapkan dapat memperbanyak referensi untuk hasil yang lebih maksimal. Untuk penelitian selanjutnya sebaiknya peneliti memperluas variabelnya maupun jumlah sub 
variabel, sehingga lebih representatif dan validasinya lebih akura

\section{DAFTAR PUSTAKA}

Abbas, Afifi Fauzi. 2015.Faham Agama Dalam Muhammadiyah. Uhamka Press. Jakarta.

Arfianto, Fajar Dan Sukanti. 2014. Pengaruh Motivasi Diri Dan Persepsi Mengenai Profesi Akuntan Publik TerhadapMinat Menjadi Akuntan Publik Pada Mahasiswa Prodi Akuntansi Fakultas Ekonomi Universitas Negeri Yogyakarta. Jurnal Nominal. Volume. 3, Nomor. 2 (2014).

Candraning, C dan Rifqi Muhammad. 2017. Faktor- faktor yang mempengaruhi minat mahasiswa bekerja di lembaga keuangan syariah. Jurnal Ekonomi \& Keuangan Islam, Vol. 3, No. 2, Juli 2017.

Fani Ap. 2015. Faktor-Faktor Yang Mempengaruhi Minat Mahasiswa Akuntansi Universitas Bengkulu Berkarir Di Entitas Syariah. Skripsi. Fakultas Ekonomi Dan Bisnis. Universitas Bengkulu: Bengkulu.

Faisal. 2016. Faktor-Faktor Yang Mempengaruhi Minat Mahasiswa Untuk Menjadi Nasabah Di Bank Syariah (Studi Kasus Mahasiswa Ekonomi Dan Perbankan Islam Universitas Muhammadiyah Yogyakarta). Skripsi. Fakultas Ekonomi dan Bisnis. Universitas Muhammadiyah Yogyakarta: Yogyakarta.

Ghozali, I. 2013. Aplikasi analisis multivariate dengan program IBM SPSS 23.Semarang : Badan Penerbit Universitas Diponegoro. Harahap, S.S. 2004.Akuntansi Islam. Cet. Keempat. Jakarta: Bumi Aksara.

Ikatan Akuntan Indonesia. 2007. Standar akuntansi keuangan. Salemba Empat. Jakarta.

Islamylia, \& Mutia, E. (2016). Pengaruh Sikap, Norma Subjektif, Kontrol Perilaku, Motivasi Spiritual Terhadap Minat Mahasiswa Akuntansi Dalam Memilih Konsentrasi Akuntansi Syariah Di Fakultas Ekonomi Universitas Syiah Kuala. Jurnal Ilmiah Mahasiswa Ekonomi Akuntansi (JIMEKA), 1 (1), 192-203.

Imroatullayyin Makhfiyana Dan Imakhfiyana.2013. Rasionalitas Plagiarisme Di Kalangan Mahasiswa Fakultas Ilmu Sosial UNESA. Jurnal Paradigma. Vol. 01 No. 3.

Jamaluddin, Syakir. 2013. Shalat Sesuai Tuntunan Nabi Saw. LPPI UMY. Yogyakarta.

Kariyoto. 2013. Akuntansi dalam perspektif syariah Islam. JurnalJIBEKA. Volume 7 No 2 Agustus 2013: 44 - 51 .

Linda, Dan Iskandar Muda. 2011.'Pengaruh Pengetahuan Akuntansi dan Motivasi Terhadap Minat Mahasiswa Akuntansi Perguruan Tinggi Negeri dan Swasta di Provinsi NAD Untuk Mengikuti Pendidikan Profesi Akuntansi (PPAK)”. Jurnal Keuangan dan Bisnis, Vol. 3, No. 2.

Machmud, A \& Rukmana 2010. Bank Syaria: Teori, Kebijakan, dan Studi Empiris di Indonesia. Yogyakarta: Erlangga

Muslim, Sarip. 2015. Akuntansi Keuangan Syariah Teori \& Praktik. Bandung: CV Pustaka Setia.

Marliani, Rosleny. 2013. Hubungan antara religiusitas dengan orientasi masa depan bidang pekerjaan pada mahasiswa tingkat akhir. Jurnal Psikologi. Vol 9 No. 2 Desember 2013.

Mahayani, made dwi, Sulindawati, gede erni, \& Herawati, nyoman trisna. (2017). Pengaruh 
Persepsi, Motivasi, Minat, dan Pengetahuan Mahasiswa Akuntansi Program SI Tentang Pajak Terhadap Pilihan Berkarir Dibidang Perpajakan.

Makhsun Ali, W. 2018. Analisis Faktor-Faktor Yang Mempengaruhi Minat Mahasiswa Fakultas Ekonomi Dan Bisnis Islam Iain Salatiga Untuk Berkarir Di Bank Syariah. Skripsi. Fakultas Ekonomi dan Bisnis Islam. Institut Agama Islam Negri Salatiga.

Mahmudah, Niswatul. Analisis Faktor-Faktor Yang MempengaruhiMinat Mahasiswa Stei Sebi Jurusan Akuntansi Syariah Terhadap Profesi Akuntan Publik. Jurnal Akuntansi Dan Keuangan Islam Vol 1, No. 2 (2013).

Nurhayati, S dan Wasilah. 2012. Akuntansi syariah di Indonesia. Jakarta: Salemba Empat.

Pratama, Bima Cinintya dkk. 2017. Penerapan praktek dan teori akuntansi syariah berdasarkan prinsip syariah. Journal of Accounting \& Finance. Volume 13 Number 2, Page 83-91 2017.

Qulub, A. Syaifa'ul. 2016. Pengaruh Puasa Terhadap Kecerdasan Intelektual.Jurnal pendidikan islam Vol.12, No.1 Januari 2016.

Renaldy Masse Dkk. 2015. Pengaruh Perencanaan Karir, Pelatihan Dan Pengembangan Karir Terhadap Kinerja Pegawai Pada Museum Negeri Provinsi Sulawesi Utara. Jurnal Berkala Ilmiah Efisiensi. Vol 15. No.05.

Rusman.2011. "Model-Model Pembelajaran Mengembangkan Profesionalisme Guru”. Jakarta: Rajawali Press.

Rifqi, M. 2010. Akuntansi keuangan syariah. Yogjakarta: P3EI.

Sri Rahayu, W. 2017. Pengaruh religiusitas, pengetahuan akuntansi syaraiah, pelatihan profesional dan pertimbangan pasar kerja terhadap minat mahasiswa akuntansi berkarir di lembaga keuangan syariah. Skripsi. Fakultas Ekonomi dan Bisnis Islam. Institut Agama Islam Negri Surakarta: Surakarta

Sari, M. 2013. Faktor-faktor yang mempengaruhi pemilihan karir menjadi akuntan publik oleh mahasiswa departemen akuntansi fakultas ekonomi Umsu Medan. Jurnal Riset Akuntansi Dan Bisnis Vol 13, No. 2.

Suyono, Nanang Agus. 2014. Analisis faktor-faktor yang mempengaruhi pemilihan karir sebagai akuntan publik. (studi emperis pada mahasiswa akuntansi UNSIQ).Jurnal PPKM, ISSN: 2354-869X. halaman 69-83.

Sila, Mursalim, dkk. 2017. Faktor- Faktor Yang Mempengaruhi Minat Mahasiswa Akuntansi Untuk Berkarier Di Lembaga Jasa Keuangan Syariah. Jurnal Prosiding Seminar Hasil Penelitian (Snp2m). Vol 3, No. 22017.

Sugiyono.2010.Metode penelitian bisnis. Bandung: Alfabeta.

Syafiq, Ahmad. 2015. Zakat Ibadah Sosial Untuk Meningkatkan Ketaqwaan Dan Kesejahteraan Sosial.Jurnal Ziswaf. Vol. 2, No. 2, Desember 2015.

Sugiyono . 2014. Metode Penelitian Kuantitati, Kualitatif, dan Kombinasi (Mixed Methods). Bandung: Alfabeta.

Tyas, S dan Rizky Tri Asmono. 2017. Penerapan gini index dan k-nearest neighbor untukKlasifikasi tingkat kognitif soal pada taksonomi bloom. Jurnal Pilar Nusa Mandiri Vol. 13, No. 2 September 2017.

Widyastuti, S dan Juliana. 2004. Pengaruh motivasi terhadap minat mahasiswa akuntansi untuk mengikuti Pendidikan Profesi Akuntansi (PPAk). Simposium Nasional 
Akuntansi VII: Yogyakarta.

Wulantami Ardina. 2018. Pilihan Rasional Keputusan Perempuan Sarjana Menjadi Ibu Rumah Tangga. Jurnal Dimensia. Vol. 7. No. 1.

Yulianti, Rahmah. 2015. Pengaruh minat masyarakat Aceh terhadap keputusan memilih produk Perbankan Syariah di Kota Banda Aceh. Jurnal Dinamika Akuntansi Dan Bisnis, vol.2, No.1, Maret 2015. 